\title{
BOTTOM-UP AND TOP DOWN APPROACHES FOR URBAN AGRICULTURE
}

\author{
Chiara Casazza ${ }^{1}$ and Stefano Pianigiani ${ }^{2}$ \\ ${ }^{1}$ CISDU Centro Internazionale di Studi sul Disegno Urbano, University of Florence, \\ Italy \\ ${ }^{2}$ Department of Architecture DIDA, University of Florence, Italy
}

\begin{abstract}
Urban Agriculture, developed in several forms according to different contexts, is a trend that is acquiring strength as it responds to the common need of a sustainable city in terms of environmental, economic, social and institutional sustainability..

Urban Agriculture is a complex phenomena that involves different kind of approaches and intervention typologies such as low tech and high tech solutions (from community gardens to vertical farms), that characterizes the city at different scales (territory, town, neighbourhood, building and house), and that responds to several exigencies and requirements fitting different users.

The paper aims to classify and describe the different typologies of integration of agriculture in urban areas and its environmental, social and economics implications starting by dividing them according to the main approaches identified: bottom-up approach, top-down and commercial approach.
\end{abstract}

\section{KEYWORDS}

Urban agriculture, urban requalification, urban design, sustainable city

\section{URBAN AGRICULTURE: A STRATEGY FOR THE SUSTAINABLE CITY}

Contemporary towns in the developed world need to face several problems in terms of sustainability, health, quality of life and environment: lack of green spaces, bad air quality, bad water management, degrade, abandoned spaces and low environmental quality. Furthermore food need is a criticism affecting huge urban areas as it implies: vast land exploitation, pollution due to transports and crop methods, resource consumption. In this context urbanization and globalization brought out other issues such as health and alimentary diseases, and loss of food awareness, due to lack of education and separation between food production and consumers.

In a large number of countries a trend is emerging as a possibility to face those challenges above mentioned: urban agriculture. With this term we can define an industry [15] located within of a town which grows or raises, processes and distributes a diversity of food and non-food products, using mainly human and material resources [16], inputs and services found in the urban area, and sharing outputs and ecosystem services to the city itself. Urban agriculture it's definitely an issue that involves different disciplines, and it consists in a range of agricultural (and related to) activities that take place in a urban context.

Recently, projects in the field of architecture and planning, that aim to integrate food production in urban built and open space, with different spatial and architectonical solutions, with different implications and with several performances, are spreading also in the most important cities of North America, and Europe.

DOI:10.5121/civej.2016.3204 
Indeed, if developing countries urban agriculture is diffused as a strategy in order to guarantee food security and healthy food access, in the above mentioned areas the phenomena is enriched with other features and values such as sustainability and alternative food models. In these contexts urban food production is distinguished by a multifunctional feature [14] and eco-systems services creation, and furthermore it responds to certain sheared exigencies: short food chain, proximity between consumers and production [19], environmental and alimentary education, citizens' participation and inclusion, social help, town management, city greening and shared green spaces, urban requalification, wellbeing, health [5] .

It is immediately clear how crop production it's only the first issue concerning urban agriculture, as it carries different meanings and performances: city greening (carrying all the consequential benefits), agriculture environmental footprint reduction (in terms of transport and soil consumption), local $\mathrm{Km} 0$ production enhancing the local retail market, new jobs, wellbeing, education and health (due both to the conscious consumption of food and the farming activities), social inclusion.

Urban agriculture is definitely a complex phenomenon, which involves different discipline and approaches, and which it's acquiring interest and attention in the field of architectural research as considered a strategy for urban regeneration actions.

As aforesaid the last few years it's possible to identify a large number of projects that aim to integrate agriculture at urban and building scale, non only making existing green areas suitable for food production, but also using alternative urban and building spaces such as courtyards, pocket spaces, brownfield sites, flat roofs, terrace, also taking advantage of innovative high tech devices.

What needs to be highlighted is the fact that urban agriculture is one of the actions and strategies enhanced by all the Urban Food System plans or strategies [9] , showimg furthermore the will of re-design the city "with food in mind", linking urban, food planning and space and buildings design. Thus Public Administrations that adopted urban food strategies are well aware of urban agriculture's value and impact toward the city and of the fact that its strength appears especially if it is included in a productive green infrastructure, a food network in the city for the city itself.

\section{Urban Agriculture Project Analysis}

Designing and integrating agriculture in urban settlements needs an holistic and management approach, as various issues and stakeholders are involved: indeed the urban one is a complex environment under a physic, spatial, economic, cultural, landscape, social, administrative and also historic point of view, and urban agriculture, just like all the other space typologies and uses, needs to relate itself to all of these aspects. Moreover the role that urban agriculture can play it's multiple according to its declinations: community gardens and Jardins Partagés, allotment gardens, backyard gardens and household vegetable gardens, pocket vegetable gardens, commercial and entrepreneurial urban agriculture, urban commercial greenhouses, educational and school urban agriculture, vertical farms.

An analysis of the literature review about the theme, and of international and heterogeneous case studies, showed a various range of possibilities for our cities tackling social, economical and environmental sustainability. The research underlined how urban agriculture consists of a complex phenomena that involves different kind of approaches and intervention typologies such as low tech and high tech solutions that characterizes the city at different scales (territory, town, 
neighborhood, building and house), and that responds to several exigencies and requirements fitting different users.

What emerged from the analysis and the review was the difficulty of an urban agriculture typologies classification. Indeed its declinations might be classified according to the kind of space involved (rooftop, façade, garden etc.) or according to the project aim (educational, commercial farm) or furthermore according to the project technology (urban green house, hydroponic vertical farm etc.). According to that in order to describe urban agriculture possibilities and group its declination the following main approaches were identified: bottom-up, top-down and commercial approach.

Under the definition of bottom-up approach are identified those interventions that originate from the users, from the citizens themselves, that take possession (sometimes also independently) and modify spaces giving them new quality and function (that might be, agricultural, social and enhancing participation and social inclusion). They consists of all those cases where the citizens show the need of urban green productive spaces for different aims, that might range from selfsufficiency production to social inclusion, and that sometimes involve Public Administrations in order to create urban farming spaces and facilities, but on the other hand sometimes take independently and even illegally possession of public spaces.

We can cite the emblematic example of the Jardins Partegés in Paris: the Mairie of Paris developed a legal framework and procedure in order to authorize forms of community and shared vegetable gardens in urban empty lots. Indeed the practice started to spread autonomously and illegally, as citizens took possesion of urban lots for farming and social participation aims. Later on the Public Administration saw the advantages of regulating this kind of interventions, defining specific procedure for land concession and use.

But under the bottom-up urban agriculture approaches we can also cite all those forms of informal urban vegetable gardens, that usually develop in abandoned areas and in neglected or marginal spaces such as along railways, rivers or roads.

Furthermore home gardens, that might develop in backyard gardens, private terraces, balconies, shared private spaces, or even indoor, are definitely forms of bottom up urban agriculture as they become firstly a possibility for owners to grow their own food and secondly to have their own green space enhancing life quality, wellbeing, healthy diet, awareness toward food, conviviality.

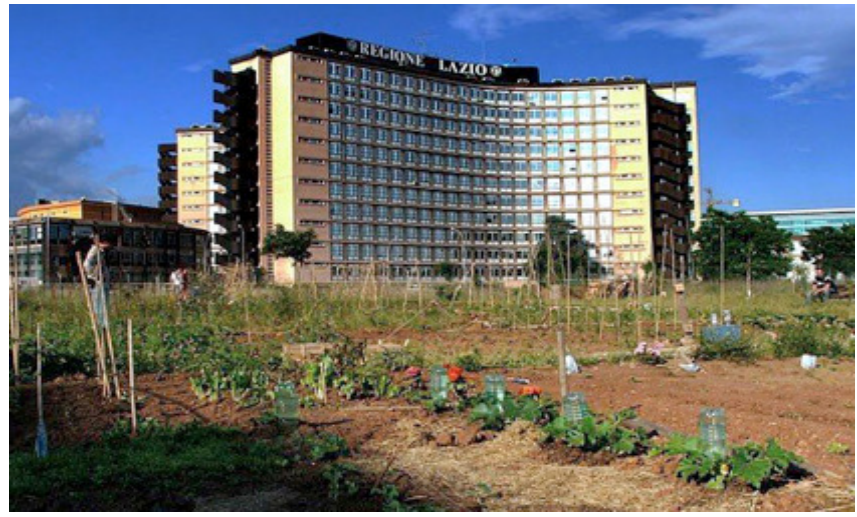

Figure 1. Spontaneous and selfmanaged vegetable garden in Rome 
The top-down approach involves those cases supported by a plan or a project that aim to introduce urban agriculture in order to produce or sell food and especially to modify people habits and make them aware of the importance of a sustainable production of local healthy grown food. They consists of all those cases when a Public Administration or an associations develops an urban agriculture project in order to enhance urban requalification, education, awareness, social inclusion. An interesting case in this direction is the project London Capital Growth, in partnership between London Food Link, the Mayor of London, and Big Lottery's Local Food Program, that aims to create hundred acres of urban food growing space, aiming to institutionalize the practice of urban food growing and furthermore to locate it in the strategic city planning with the Greater London Authority.

Another emblematic examples of top-town approaches toward urban agriculture are the educational farms projects. They consist of operations of integrating agriculture in urban contexts, aiming to create a place for education and disseminations toward alimentation, diet, health and food growing. Interesting examples in this case are the Science Barge, an innovative and sustainable hydroponic floating greenhouse built to enhance educational activities and research in the field of food growth but also energy efficiency and sustainability in food production. Moreover there are a few examples all over the world of didactic or even therapeutic vegetable gardens realized in schools or in healthcare structures.

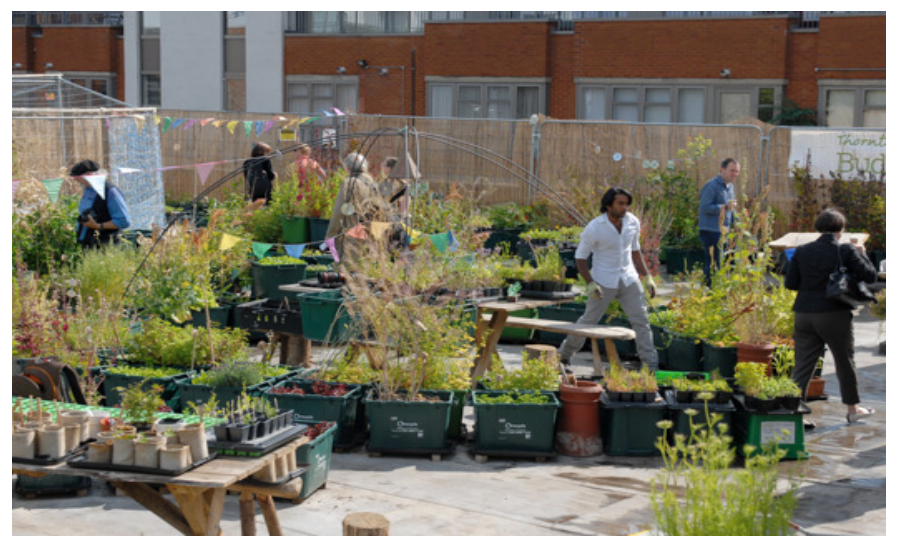

Figure 2. London capital Growth

The last, the commercial approach toward urban agriculture includes all those examples of entrepreneurial urban agriculture, urban agri-business [11], especially spreading in North America and that take advantage of urban agriculture to create new business in the filed of local and $\mathrm{Km} 0$ food market, and that might concern selling, serving, packaging, transport and featured services. These examples consist of actual business or enterprises that produce and sell food products in urban contexts. Notable examples are those of Lufa Farms, Gotham Greens, BrighFarms, and Brooklyn Grange: which grow and sell their products to local supermarkets, the firsts taking advantage of hydroponic and high tech greenhouses built on top of abandoned industrial buildings and the last one harvesting on an green roof. Furthermore Bell Book and Candles restaurant in New York needs to be cited: the first restaurant to grow and serve products harvested directly on the roof of its building taking advantage of hydroponic growing towers. 


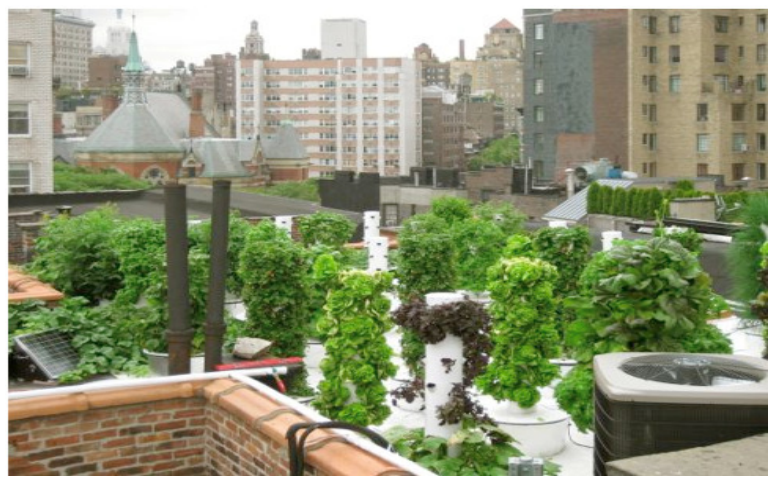

Figure 3. Bell Book and Candles restaurant hydroponic fooftop farm

According to the different approaches identified and to the very different project typologies and aims, different technologies are applied in order to integrate food production in urban settlements both at urban and at building scale with forms of Building Integrated Agriculture [2].

Different technologies are furthermore investigated or adapted (and transferred) from agriculture to architecture (greenhouses, hydroponic growing systems, containerized growing) in order to make the abovementioned spaces suitable for crop production. In particular designers can take advantage of a variety of devices which range from traditional growing systems (in ground, in vase, raised beds, greenhouse, green roof, vertical green) to high tech usually hydroponic (soilless/soil or soil simulant) growing systems devices (greenhouse, growth-cell, hydroponic vase, hydroponic tower, vertical farm, vertical green and living wall). These last ones are especially suitable in case of artificial surfaces and when lightness, productivity and crops protection from urban pollution are highly required.

The case studies review showed how urban agriculture is declined at different scale, in different space typologies, both in open spaces (gardens, parks, unused spaces) and integrated at building scale (green roofs and vertical greening), with different performances and technologies in each case.

\section{URBAN AGRICUltURE BOTTOM UP AND TOP DOWN APPROACHES}

In order to classify in terms of the possibilities of integration of agriculture in urban areas the mentioned approaches were identified. The three aim to meet the same general needs (urban greening and requalification, shortening the distance between food production and consumers, social education and participation) but tackle different specific objective and are especially developed in different ways. Indeed in the current paper are described urban agriculture examples in developed countries of the "northern globe", in in big cities and megalopolis, which shear the same needs. Of course there are differences between the exigencies emerged according to different countries: for instance in Italy the emergency of locally grown food and alimentary education is less urgent (as local markets are present in many towns and local farmers are involved) compared to the U.S. where food happens to travel thousands miles to reach the urban supermarkets or retailer and that is facing an emergency in the field of alimentary diseases and lack of alimentary education. Moreover in a country like Holland where land use and land management have always been basilar we can assist to diffuse, planned and legally regulated examples of urban agriculture and urban farming. 
Civil Engineering and Urban Planning: An International Journal (CiVEJ) Vol.3, No.2, June 2016

Each one of the main features and approaches identified will be described, aiming to frame different approaches and strategies in urban agriculture, in terms of:

- Scale and type of space hosting the project

- Project objectives

- Users involved

- Growing devices and technologies

\subsection{Bottom-Up Approach}

In this group are included both private and autonomous forms of urban agriculture, as those carried out in private residential spaces, and spontaneous ones, as those where a group or an association of people manages an urban public space for agricultural uses, or even illegal or spontaneous forms.

Scale and type of space

This kind of urban agriculture is usually pursued at small scale as it usually has to be managed by a single person or by groups of people. Typical space typologies are:

- private building spaces: balconies, terraces, indoor space, private gardens

- shared building spaces: flat rooftops, courtyards, shared gardens

- unused urban space: vacant lots, marginal areas, empty space along railways ,rivers and infrastructures, pocket spaces

\section{Project objectives}

This form of urban agriculture usually aims to local food production for self consumption, but also addresses and enhances environmental sustainability and green public shared spaces creation, community involvement, food security and food justice, educational, recreational and rehabilitator activities. These projects furthermore aim to shortening the distance between food production and consumers in order to guarantee healthy food access to citizens.

Users involved

It usually implies participatory design and volunteering for its realization and maintenance. Main users are:

- private owners or private occupants

- groups and association managing the space

- children, old people, farmers, and anyone who is taking advantage of urban agricultural activities

Public Administration by the way might be an actor of the process.

\section{Growing devices and technologies}

This form of urban agriculture usually implies low tech sustainable (while no pesticides or chemical fertilizers are used) traditional agricultural technologies as harvesting activities are pursued on the ground or in containers placed on balconies, terraces and rooftops. 
Examples

Jardin Partagés in Paris: in town were established more than 50 community gardens created and managed by small neighbourhood associations in small plots of land given in concession by the Municipalité.

Zappata Romana in Rome: it is a project that has the objective to promote community gardens in Rome as a collective action of urban public space appropriation to encourage environmental, economic and social practices.

Guerrilla Gardens: with term are identified those autonomous action of possession, carried out by group of activist, of a piece of land or an abandoned site or area not cared for by anyone. The land is so used by guerrilla gardeners to raise plants and food crops. There are some examples of active groups in U.S.A, U.K., Denmark and Australia

\section{Considerations}

This approach needs institutionalization and the definition of local policies for the space management and space usage. Furthermore users need to be trained and informed toward the possibility of urban soil and water contamination, especially when pursuing traditional in ground agriculture.

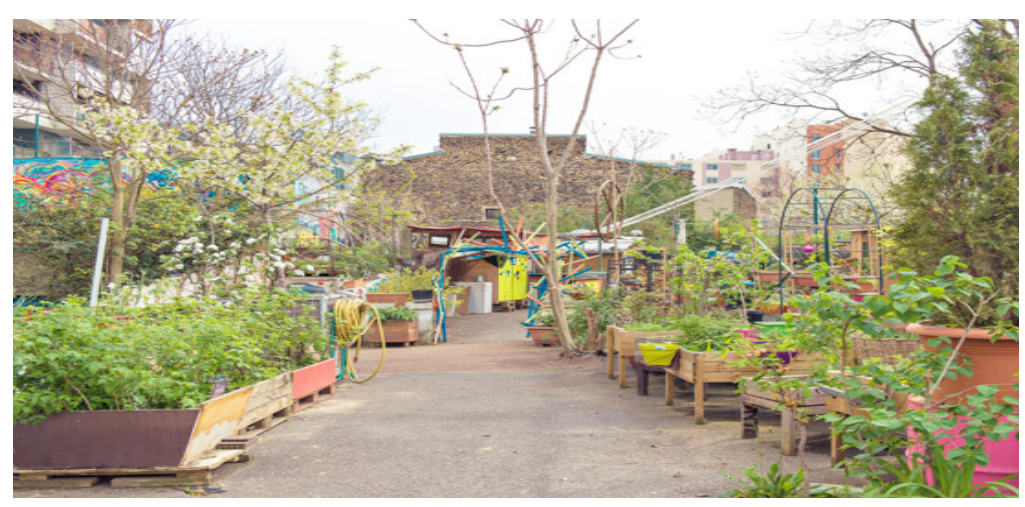

Figure 4. Jardin Partegé in Paris

\subsection{Top-Down Approach}

\section{Scale and type of space}

This kind of urban agriculture might be pursued both at building and urban scale, at small or large or even territorial scale as its influence might address the whole urban context.

The space typologies that host this kind of interventions are:

- urban public or publically enjoyed space: parks, gardens

- unused space: marginal space, vacant lots, brownfield sites, wasteland

- private or privately managed gardens or open spaces gardens (also belonging also to schools, universities, healthcare centres or associations)

- private or privately managed buildings or flat rooftops ((also belonging also to schools, universities, healthcare centres or associations or even to unused buildings 
Project objectives

This form of urban agriculture aims to:

- create educational, recreational and rehabilitator activities.

- improving of urban environmental quality and urban regeneration

- shortening the distance between food production food production enhancing education and awareness

- social inclusion and participation

- therapy

- research

- urban requalification and regeneration

\section{Users involved}

- public administrations or no-profit associations are involved in the realization and in the management of urban agriculture facilities and activities

- school, educational and healthcare centres might take advantage of urban agricultural activities

- children, elderly people, citizens and anyone who is taking advantage of the place in terms of education, recreation and food production

- public administrations are involved in the realization of green productive areas linked to urban regeneration and requalification projects

\section{Growing devices and technologies}

This form of urban agriculture usually implies both low tech sustainable (no pesticides or chemical fertilizers are used) traditional agricultural technologies (in ground, in vase,in raised beds), and building greening devices ad components (greenhouse, green roof, vertical green) but also high tech hydroponic technologies and devices (greenhouse, growth-cell, hydroponic vase, hydroponic tower, vertical farm, vertical green and living wall) according to the specific project aim and dimension.

\section{Examples}

Science barge New York: it consists of a prototype, sustainable (zero emissions and zero runoff) urban floating greenhouse and environmental education centre. It is part of a bigger project that builds innovative science labs in urban schools, and that through the Greenhouse Project Initiative uses hydroponic farming technology to educate students about sustainability.

OrtoinCondotta: it is a project pursued by the Italian Slowfood association which aims to include vegetable gardens in order to enhance environmental and agricultural didactic activities in elementary schools. Vegetable gardens are usually created in school gardens or using vases and containers, and are managed by pupils and teachers. Sometimes food is served in the school canteen.

Gary Comer Youth Centre Rooftop Garden consists of a green productive roof created on the top of the mentioned therapeutic and rehabilitation centre, that aims to create a safe, recreational and educational space for children far from the problems and the violence of the neighbourhood it is placed in. 


\section{Considerations}

This approach requires planning and administration involvement in terms of policies involved, urban planning, land management, water, wastes and energy management, public projects and public funding, urban design and urban requalification projects strategies.

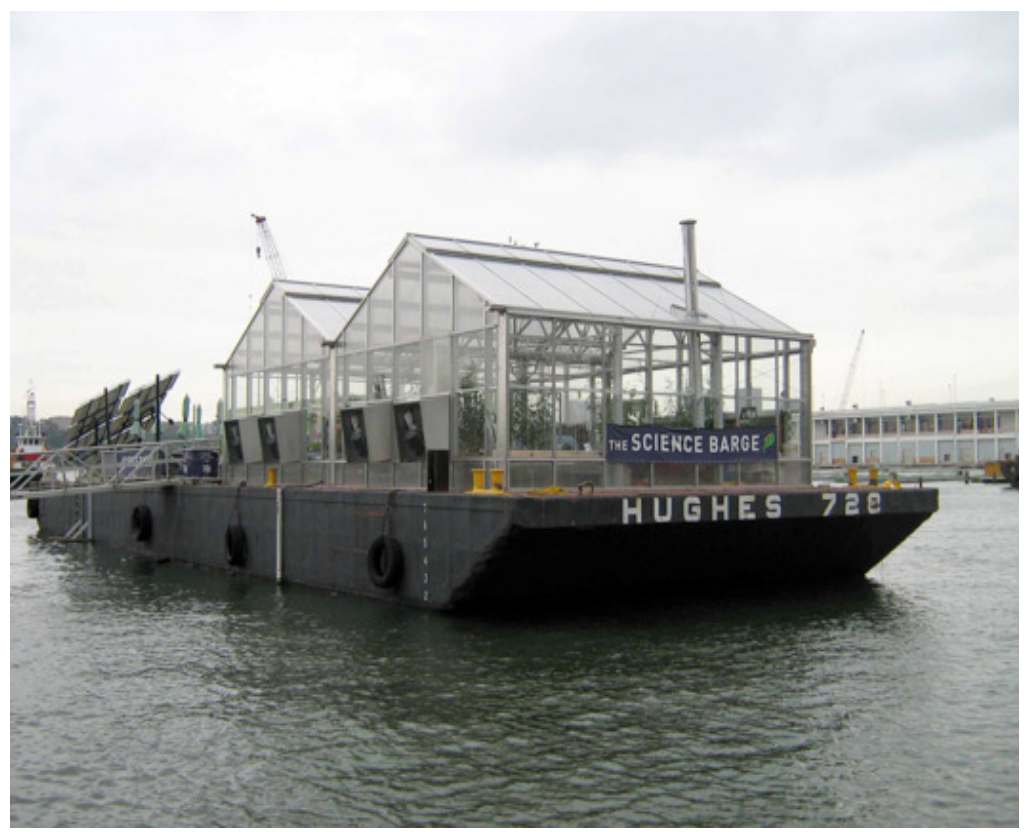

Figure 5. The Science Barge

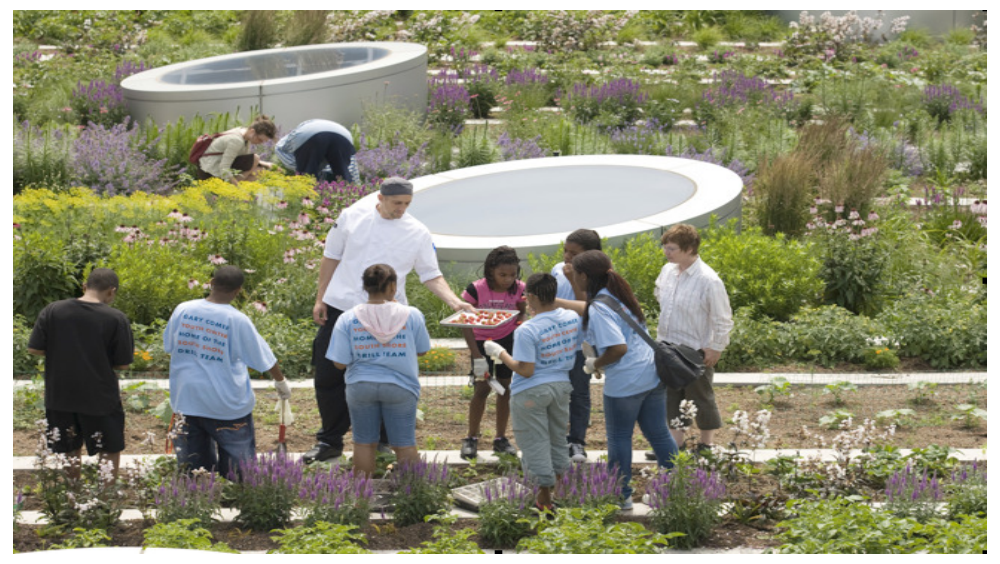

Figure 6. Gary Corner Youth Center rooftop farm

\subsection{Commercial Approach}

\section{Scale and type of space}

This kind of urban agriculture might be pursued both at small scale and at urban or even territorial scale. Indeed even if the production occupies the space of greenhouse, its influences and management involves retailers, farmers, users and administration at a larger scale. 
The space typologies that host this kind of interventions are:

- parks, new neighbourhood developments

- private ore privately managed gardens or open spaces

- private ore privately managed buildings or flat rooftops (even belonging to unused buildings)

\section{Project Objectives}

This form of urban agriculture aims to:

- reach a local food production to be sold at urban scale

- create an new local economic market or network

- create new jobs and services at urban scale

- shortening the distance between consumers and food production- selling -serving creating new business models and responding to citizens needs of awareness and sustainability

Users involved

It usually implies private designing and management. Users involved are:

- public administrations or entrepreneurs involved in the realization and in the management of urban agriculture facilities in urban areas

- retailers, supermarkets, restaurants and private buyers that will take advantage of the local production

- employed, children, old people, farmers, and anyone who is taking advantage of the place in terms of education, recreation and food production

- public administrations involved in the realization of green productive areas linked to urban regeneration and requalification projects

Growing devices and technologies

This form of urban agriculture usually implies highly productive harvesting methods with different approaches if growing is pursued at building scale or at urban scale.

In forms of building integrated agriculture projects usually take advantage of high tech and highly productive hydroponic technologies and hydroponic greenhouses that join the needs of sustainability, lightness and secure productivity, or furthermore can imply the use of green roofs technologies in case of rooftop farming. When agriculture is pursued at urban scale, it may also imply lowtech sustainable forms of growing technologies (in ground, in vase, in raised beds),

\section{Examples}

BrightFarms New York: it is a company that finances, designs, builds and operates greenhouse farms in urban areas and, through particular agreements, sells products to local supermarkets and retailers. The greenhouse already built, on the top of flat roof, takes advantage of hydroponics technologies. The aim is to bring in New York fresh and healthy locally grown food.

Vertical farms: they are the symbol of the high tech possibility of urban agriculture. Despite utopian architectural designs representing vertical farm buildings, some of them were already built, as responding to the need of locally produced healthy food in case of lack of space and land to cultivate, as Sky Green Vertical farm in Singapore or The Plant in Chicago.

Milan Parco Agricolo: a project that includes farming activities and linkages to the local farmers markets network in the town's green belt. 


\section{Considerations}

This approach requires planning and administration involvement in terms of land use, space and building regulations, and especially in terms of business feasibility (selling agreements, land use agreements, commercial networks ).

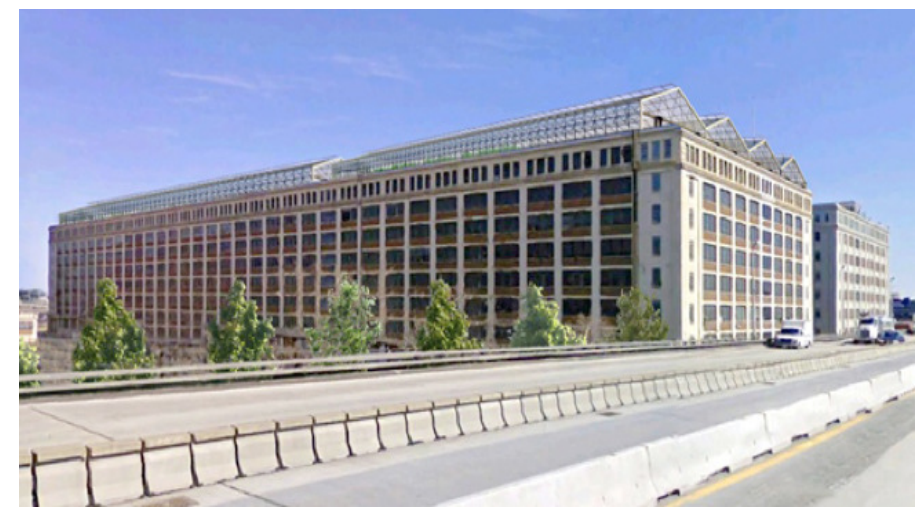

Figure 7. Bright Farms rooftop greenhouses
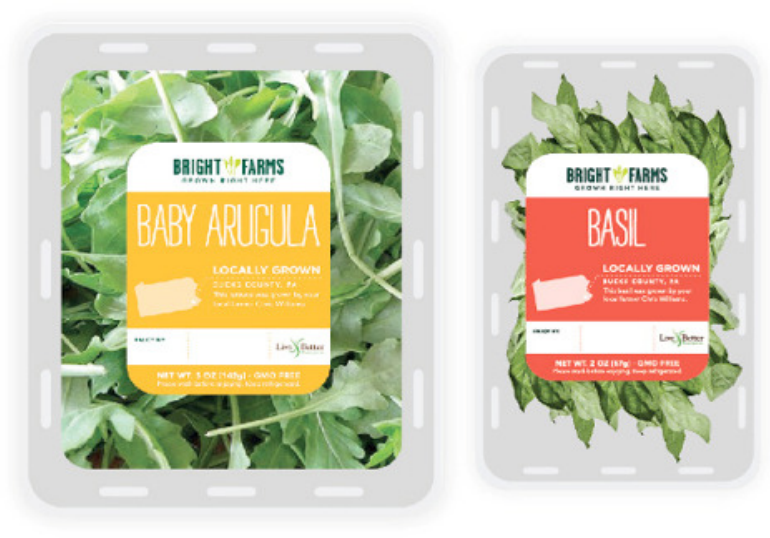

Figure 8. Bright Farms products

\section{Conclusions}

In conclusion urban agriculture is a viable strategy in order to trigger a new green productive infrastructure, while activating a network of social, commercial and recreational activities, in addition to environmental benefits due to urban greening and sustainable resources' management [1]

Urban agriculture couldn't be able to provide for an entire city food needs, just like the present economical model would not be replaced, but it might become the core element of a new approach oriented to sustainability and relationships between food and city.

This trend clearly arises in various expression and involves urban and architectural design at different levels, from planning, to new types of public space design (community gardens, agricultural parks, pocket vegetable gardens), to designing the integration between harvesting and built space (on flat roofs and through devices such as green roofs or greenhouses), until the 
design of technological components. Indeed different kinds of intervention and approaches to urban agriculture were distinguished and investigated according to different exigencies inputs, different groups of users, social involvement, technological choices, economic investment, and architectural design, also including their value, as a strategy toward urban revitalizing and requalification, in the debate on un urban sustainability.

Architects, designers and planners, but also decision makers, need to be aware of the potential of this trend and, following the examples of the firsts Food Charts [9] , and need to include and consider it in urban regeneration politics becoming familiar to its declinations and possibilities.

\section{REFERENCES}

[1] Angotti, T (2015) "Urban agriculture: long-term strategy or impossible dream? Lessons from Prospect Farm in Brooklyn, New York” Public Health Journal N. 129 p.336-341

[2] Astee, L.Y., Kishnani, N.T. (2010) "Building Integrated Agriculture: Utilising Rooftops for Sustainable Food Crop Cultivation in Singapore" Journal of Green Building Vol. 5, No. 2, pp. 105

[3] Bellows, A.C.(2004) Healthe Benefits of Urban Agriculture, Bellows,A.C., Brown, K. Smit, J. Community Food Security Coalition's North America Initiative on Urban Agricultire Portland, Community Wealth.org

[4] Bellows, A.C., Nasr, J. (2010) "On the past and the future of the urban agriculture movement: reflections in tribute to Jac Smit" Journal of Agriculture, Food Systems, and Community Developmen (http://www.agdevjournal.com)

[5] Carrabba,P., Di Giovanni B., Iannetta M., Padovani L.M. (2013) "Città ed ambiente agricolo:iniziative sostenibili verso una Smart Citu. L'evoluzione dei rapporti tra la città e l'ambiente agricolo circostante apre nuove interessanti prospettive alla sostenibilità ambientale e produttivi e a nuovi modelli di approvvigionamento alimentare per le aree urbane" Energia ambiente e innovazione rivista bimestrale Enea n. 6, p 21-26

[6] FAO Food and Agriculture Organization of the United Nations (2000) http://www.fao.org/docrep/017/x4400e/x4400e.pdf

[7] Friedman, Y. (2010) I nuovi ruoli dell'abitare e dell'architetto: Il tetto e il cibo , I nuovi ruoli dell'abitare e dell'architetto: su alcune possibili soluzioni in Friedman, Y. (Ed) L'Architettura di Sopravvivenza , una filosofia della povertà, Bollati Boringhieri Editore Torino p. 64-73

[8] Gorgolewski, M., Komisar, J., Nasr, J. (2011) Carrot City, Creating Places for Urban Agriculture, The Monacelli Press, New York, NY

[9] Hardmana, M., Larkhamb, P.J. (2014) “The rise of the 'food charter': A mechanism to increase urban agriculture " in Land Use Polic Journal y .39 p.400-402

[10] Jasma, E., Veen, E., Sukkel ,W., Visser, A.J.,"Urban agriculture and local food production: feeding our cities future" Wanningene UR for quality life" Wageningen University \& Research Centre, https://www.wageningenur.nl/upload_mm/3/0/d/bd72e939-609f-4cb3-afa9 c8c4c61aa26e_UrbanAgriculture_small.pdf

[11] Kaufman, J., Bailkey, M.,. (2000) Farming Inside Cities: Entrepreneurial Urban Agriculture in the United States, Lincoln Institute of Land Policy Working Paper http://www.urbantilth.org/wpcontent/uploads/2008/10/farminginsidecities.pdf (ultima visita: Gennaio 2015).

[12] Kulak, M., Graves, A., Chatterton, J.,(2013) "Reducing greenhouse gas emissions with urban agriculture: A Life Cycle Assessment perspective" in Land Use and Planning Journal 111 p. 68-78

[13] La Greca, P., La Rosa, D, Privitera,R., Martinico, F., (2011) “Agricultural and green infrastructures: The role of non-urbanised areas for eco-sustainable planning in a metropolitan region" Environmental Pollution Journal 159 p. 2193-2202

[14] La Rosa, D., Barbarossa,L., Privitera,R., Martinico, F., (2014) “Agriculture and the city: A method for sustainable planning of newforms of agriculture in urban contexts" Land Use Policy Journal p. 290303

[15] Mougeot L.J.A., (2000) Urban agriculture: definition, presence, potentials and risks, in Bakker N, Dubbeling M, Guendel S, Sabel Koschella U, de Zeeuw H (Ed) Growing Cities, Growing Food, Urban Agriculture on the Policy Agenda, DSE, Feldafing, D, pp. 1-42 
Civil Engineering and Urban Planning: An International Journal (CiVEJ) Vol.3, No.2, June 2016

[16] Smit, J. Nasr, J. (1992) "Urban agriculture for sustainable cities: using wastes and idle land and water bodies as resources" Environment and Urbanization, Vol. 4, No. 2, October 1992

[17] Philips, A. (2013) Designing Urban Agriculture: A Complete Guide to the Planning, Design, Construction, Maintenance and Management of Edible Landscapes, Wiley, Hoboken, NJ

[18] Taylor, J.R., Lovel, S.T. (2012) "Mapping public and private spaces of urban agriculture in Chicago through the analysis of high-resolution aerial images in Google Earth" " in Land Use and Planning Journal 108 p. 57-70

[19] Viljoen, A. (2005) Continuous productive urban landscapes: designing urban agriculture for sustainable cities, Elesevier Architectural Press, Oxford,UK, 304 p.

\section{Authors}

Chiara Casazza, Architect and Ph.D, research fellow at the University of Florence Deepartment ofArchitecture, is investigating the themes of smart city, green infrastructure, urban agriculture, urban regeneration and hydroponic technologies for urban greening.

Stefano Pianigiani, Enegineer, member of the CISDU International Centre on Urban Design, is investigating the themes of urban planning, urban design and urban regeneration.
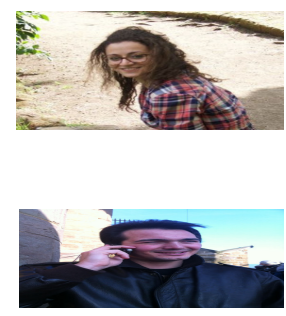